\title{
Utopia dividida: a crise do PCB (1979-1992)*
}

\author{
Fabricio Pereira**
}

\section{Introdução}

Esse trabalho aborda a trajetória do Partido Comunista Brasileiro (PCB) ao longo da abertura e transição democrática. O PCB oscilou ao longo de sua trajetória entre a adesão a um projeto revolucionário e tendências mais reformadoras em sua praxis e mesmo em seus objetivos declarados; entre os exemplos internacionais do "socialismo realmente existente" e a dura realidade brasileira; entre a opção de se constituir num partido de massas ou assumir o papel de "partido de quadros" (tendo por objetivo o "assalto" ao poder); entre a via pacífica ao socialismo e a insurrecional. Com todas as dificuldades, atravessou décadas lutando por uma sociedade que seria mais humana e fraterna, a "sociedade socialista do futuro" que não chegou.

No período entre 1979 e 1992, o PCB perdeu definitivamente seu papel hegemônico e referencial no campo das esquerdas para uma nova agremiação (o Partido dos Trabalhadores - PT, fundado em 1980) e assistiu à erosão de suas bases sindicais. Na seqüência, com a tão aguardada legalidade em 1985 (Desde 1947 o partido era considerado extinto pela Lei Eleitoral ), os pecebistas foram obrigados a amargar ínfimos resultados eleitorais. Tudo isso à revelia da vitória do caminho defendido pelo

\footnotetext{
* Este artigo é versão resumida de minha dissertação de mestrado, que contou com o apoio do CNPq para sua realização.

** Doutorando em Ciência Política pelo Instituto Universitário de Pesquisas do Rio de Janeiro (IUPERJ).
} 
partido (e combatido por vários outros grupamentos de esquerda) para a superação da ditadura: pacífico, negociado, progressivo. Tiveram que conviver com crises internas que custaram esporádicas cisões e com a crise que acometeu o "mundo socialista" e o pensamento marxista em geral. Tudo isso culminou na divisão do PCB. Nas páginas seguintes, serão comentados os principais movimentos do partido nesse período, e sistematizados os fatores que em minha avaliação mais contribuíram para a sua crise. Tal período pode ser considerado como o da "grande crise" do PCB. A narrativa será entremeada por trechos de depoimentos orais colhidos por mim ao longo do período de pesquisa ${ }^{1}$, e secundariamente por passagens retiradas de documentos, revistas e jornais publicados pelo partido ou por grupos organizados em torno de suas disputas internas ao longo do período estudado ${ }^{2}$, bem como de obras escritas por militantes ecoando debates partidários.

Vale fazer uma rápida constatação acerca das fontes orais aqui utilizadas. Nelas destaca-se a semelhança de discursos entre a maioria dos entrevistados ${ }^{3}$. Em vários momentos fica a impressão de que esses militantes pecebistas teriam vivido experiências semelhantes. As opiniões coincidentes, longe de representarem falta de reflexão por parte dos entrevistados ou forte coerção no interior da organização, levam a pensar na intensa e longa convivência de grupo vivida por esses entrevistados, o que levaria a certa unificação discursiva (às vezes inconscientemente). As opiniões coincidentes parecem advindas da convivência em grupo (que a

1 Colhi uma série de depoimentos de militantes das diferentes linhas de pensamento que tiveram peso no PCB durante o período analisado. Optei majoritariamente por militantes reconhecidamente representativos da vida partidária - entrevistando também alguns militantes de base, o que permitiu uma visão mais complexa do objeto. Foram entrevistados Geraldo Rodrigues dos Santos, Gilvan Cavalcanti Melo, Givaldo Siqueira, Leandro Konder, Severino Theodoro de Mello, Zuleide Faria de Melo e Zuleika Alambert.

2 Em termos de imprensa partidária, "oficial", pesquisei o último ano da fase "oficial" do jornal Voz Operária (1979), o jornal Voz da Unidade (1980-1991) e a revista teórica Novos Rumos (1986-1991). Quanto à imprensa publicada por grupos oposicionistas ou dissidentes no período, destaco a última fase do jornal Voz Operária (1980-1992), editado pelos “prestistas”, e a revista Presença (1983-1992), dos "renovadores". Outra revista consultada foi Socialismo e Democracia (1984-1988), organizada em boa parte por ex-militantes pecebistas e importante no debate acerca das esquerdas naquele período.

3 Com exceção de dois depoimentos: o de Zuleide Faria de Melo, dona de uma trajetória em vários pontos diversa dos outros depoentes, e única a participar da "reconstrução" do PCB, sendo hoje sua presidente nacional; e o de Leandro Konder, que saiu do partido em 1982 e terminou por se afastar mais decididamente dos pecebistas. 
maioria dos entrevistados mantém até os dias de hoje, no Partido Popular Socialista - PPS). Aqui fica mais que nunca evidente que a memória é construída com o passar do tempo, por meio de diversas "negociações” e seleções. A espécie de memória coletiva desenvolvida por esses depoentes "é um elemento constituinte do sentimento de identidade, [...] na medida em que ela é também um fator extremamente importante do sentimento de continuidade e de coerência de uma pessoa ou de um grupo em sua reconstrução de si” (Pollack, 1992, p. 204).

\section{O paradoxo}

A crise e a posterior "dissolução oficial" do PCB causaram perplexidade, não somente a militantes do campo das esquerdas, mas a qualquer observador que soubesse da importância daquela agremiação na história brasileira ao longo da maior parte do século XX. Um partido que chegou a ser hegemônico nas esquerdas e nos movimentos sociais, que participou em vários momentos da chamada "alta política" republicana, sem nem mesmo possuir existência legal na maior parte do tempo, passou por um grave processo de definhamento, terminando "dissolvido" (na verdade dividido). E mais: tal processo teve sua fase decisiva no momento em que as propostas do PCB para a redemocratização brasileira se tornaram majoritárias no campo oposicionista e foram finalmente vitoriosas (ainda que por caminhos tortuosos, diversos dos propugnados pelo partido).

Para ajudar a compreender esse aparente paradoxo, pode-se lançar mão da seguinte chave explicativa: o Brasil estava completando naquele período sua modernização capitalista por meio de uma "revolução passiva"4 - e a ditadura (de caráter "modernizador autoritário") constituiu-se como um passo fundamental nesse caminho. A sociedade brasileira passava com isso por profundas transformações, tornando-se assim mais complexa, com o desenvolvimento de uma pujante sociedade civil. Nesse novo contexto, teriam mais chance de êxito organizações partidárias adaptadas à nova realidade: mais democráticas, desburocratizadas, plurais.

4 O filósofo marxista italiano Antonio Gramsci lançou mão do conceito de "revolução passiva" para explicar a possibilidade de uma sociedade passar a um novo estágio de organização sem uma revolução aberta. Tal fenômeno se daria de uma maneira processual e em certos aspectos incompleta, a partir de um grande equilíbrio no processo de luta de classes. 
Para compreender esse processo, lanço mão de três hipóteses. A hipótese central aponta a persistência de concepções $e$ práticas burocráticas "centralizadoras" e mesmo antidemocráticas no PCB, quando o país completava seu processo de modernização capitalista pela "via passiva", como fator determinante para a crise geral que acometeu o partido. Tal situação levou a uma progressiva inadequação deste à sociedade que pretendia transformar, à baixa representação pecebista entre os setores modernos do "novo" movimento sindical e à paralisia interna derivada de sua progressiva divisão. Há, por fim, duas hipóteses secundárias. Uma relaciona a crise do PCB às dificuldades do partido em lidar com a transição negociada (à qual terminou atrelado em posição subalterna) da forma como se deu: uma transição "fraca", com predominância dos interesses conservadores. Enquanto isso, o PT, assumindo posição claramente contrária àquele processo, se viabilizou enquanto força hegemônica nas esquerdas e no movimento sindical. A outra aponta para a crise do "mundo socialista", que também jogou importante papel no processo (especialmente em seu final, quando este já estava em parte delineado), legitimando e reforçando tendências já presentes no PCB.

\section{Luta pela democracia, democracia em debate: o PCB na "abertura" (1979-1983)}

Praticamente desde o princípio da ditadura, o PCB se definiu pelo enfrentamento pacífico àquele regime, adotando "a tática da 'Frente Democrática'. Os pecebistas deveriam se aliar a todos os que se opunham à ditadura. O partido defendia que a derrubada do regime deveria se dar através de soluções politicamente negociadas" (Pandolfi, 1995, p. 206-7). A gênese dessa política foi assim descrita por um depoente:

O partido convocou um congresso para reafirmar a nossa linha política, em cima de cisões, de quedas, o pessoal saindo para o exílio... Então a gente tentou organizar o [VI] congresso que foi realizado em 67 e que referendou toda a nossa política de frente democrática, da questão já da Anistia, da Constituinte, nos documentos de 67 já está explicitada toda essa política de abertura política, de se trabalhar através da sociedade, para "derrotar" 
politicamente a ditadura, e não para "derrubar" a ditadura (era um conceito diferente). A "derrubada" significa a luta armada, e a "derrota" significava para nós o envolvimento da sociedade, dos movimentos políticos, da população no sentido de isolar a ditadura e dar uma saída até negociada, como na realidade aconteceu (Gilvan Cavalcanti Melo. Depoimento cedido ao autor em 30 de julho de 2003, no Rio de Janeiro-RJ).

Tal política de um modo geral se manteve ao longo de toda a ditadura, porém seu percurso não foi tão linear quanto os depoimentos colhidos nos dias de hoje podem sugerir. ${ }^{5}$ Sabe-se que essa linha política foi aprovada com grandes dificuldades em 1967 (às custas de uma grande perda de contingentes na agremiação) e que permaneceu sendo questionada por alguns, até ser abertamente atacada por Luiz Carlos Prestes e seu grupo já no exílio - e ruidosamente no retorno ao Brasil. O depoimento a seguir aponta para a permanência de uma visão crítica à "via pacífica" ao longo de todo o período: "Eu sempre achei que seria guerrilheira, sempre achei. Mas nunca fui. [...] como o PCB jamais optou pela luta armada, eu jamais saí, então evidentemente isso pra mim... Mas por outro lado, eu me impus (o que não é tão fácil) uma disciplina partidária, é também assim: num tipo de divergência, ou você é absolutamente disciplinado ou também não sobrevive" (Zuleide Faria de Melo. Depoimento cedido ao autor em 21 de abril de 2004, no Rio de Janeiro-RJ).

O período estudado começa com a extinção do Ato Institucional n. ${ }^{\circ}$ 5 e a decretação da Anistia - o que abriu novos espaços para a atuação do PCB e permitiu a volta dos dirigentes pecebistas exilados na Europa. No entanto, deve-se recordar que os pecebistas eram obrigados ainda a conviver com a ilegalidade e a repressão (ainda que numa intensidade baixa se comparada aos anos anteriores). O partido reconhecia que o quadro tinha mudado, mas não o suficiente para que sua linha política devesse sofrer alguma inflexão profunda. No entanto, não era isso o que pensavam amplos setores do quadro partidário, e a partir de 1979 se iniciou a atuação pública dos autodenominados "renovadores" - boa parte dos intelectuais

5 Em quase todos os depoimentos essa linha política surge como algo intocado ao longo de toda a ditadura, sendo inclusive um dos principais motivos de orgulho e identificação entre a atuação dos depoentes nos dias de hoje (a maioria no PPS) e naquele período. 
de renome do partido, que exigiam a democratização das instâncias partidárias e o que classificavam como o "arejamento" do ideário comunista através da concepção da "democracia como valor universal". Também dos chamados "prestistas", agrupados em torno de Prestes, que pugnavam pelo "resgate do caráter revolucionário" pecebista e por uma postura de enfrentamento aberto em relação à ditadura.

Os primeiros defendiam que a luta pela democracia não deveria ser encarada como um objetivo tático (luta por um espaço mais propício para a atuação do partido), mas estratégico, pois seria indispensável na formação de elementos necessários ao desenvolvimento socialista. Além disso, "Discordavam da visão 'etapista' do processo revolucionário e consideravam equivocada a proposta de revolução nacional-democrática, por pressupor uma subordinação da questão democrática à questão nacional" (Carone, 1982, p. 212).

Já os segundos seguiam de perto as críticas apresentadas por Prestes em sua Carta aos comunistas, de 1980: "Um partido comunista não pode, em nome de uma suposta democracia abstrata e acima das classes, abdicar de seu papel revolucionário e assumir o freio do movimento popular, de fiador de um pacto com a burguesia, em que sejam sacrificados os interesses e as aspirações dos trabalhadores" (Luiz Carlos Prestes, "Carta aos comunistas”, apud Pandolfi, 1995, p. 220). Ambos os grupos já vinham dando sinais de vida nos anos anteriores, e especificamente os problemas entre Prestes e o restante da direção se manifestaram no exílio, mas sem o conhecimento das bases do partido: "Nós aqui não sabíamos bem dessa discussão. Viemos a saber com mais clareza depois que os exilados chegaram. Até aí, se sabia que havia crise lá fora, séria, mas não sabíamos por que, qual era a causa. Depois que fomos saber" (Geraldo Rodrigues dos Santos. Depoimento cedido ao autor em 17 e 24 de setembro de 2003, no Rio de Janeiro-RJ). No entanto, somente agora se iniciava a disputa aberta em torno da linha política e do poder partidário.

Travou-se então uma das disputas internas mais difíceis da história do partido, que foi "resolvida" (se é que o termo pode ser empregado) da maneira até então tradicional entre os pecebistas. Afastadas ou isoladas as dissidências, o PCB manteve sem maiores modificações até os momentos decisivos da redemocratização sua linha política já consagrada nos anos anteriores. O núcleo dirigente buscou sua legitimação assumindo uma posição "centrista" em relação às diferentes posições em disputa. 
Na prática, o partido seguiu uma trajetória marcada por certa dubiedade, buscando equilibrar-se entre o necessário enfrentamento com o regime e o sempre presente temor de um retrocesso. Evitava-se em geral o enfrentamento aberto e a radicalização do discurso - o que, somado ao já citado temor de um retrocesso ditatorial, fez com que a atuação pecebista de um modo geral parecesse a diversos setores das esquerdas, mais do que nunca, excessivamente "reformista". O partido caracterizava o Brasil como um

[...] país capitalista industrial-agrário, com nível médio de desenvolvimento das forças produtivas, emergente nas condições da crise geral do capitalismo, da internacionalização e da interdependência do processo econômico mundial hierarquizado pelo imperialismo [...]. O capitalismo brasileiro, monopolista e integrador do latifúndio, tem como característica fundamental a sua dependência ao imperialismo (em especial o norte-americano) e articulou organicamente os mecanismos deste, dos monopólios e do latifúndio com os do Estado (Partido Comunista Brasileiro, 1983, p. 127-8).

Tal análise do capitalismo brasileiro como monopolista, relacionado intrinsecamente ao imperialismo e com resquícios pré-capitalistas (a presença do latifúndio) levou à definição do processo revolucionário como "anti-imperialista, anti-monopolista e anti-latifundiário":

No campo dos exploradores destacam-se o imperialismo [...], os monopólios e o latifúndio, articulados organicamente com o Estado. Eles são os principais exploradores e opressores não apenas do proletariado, mas ainda dos camponeses e das camadas médias urbanas - isto é, do povo brasileiro -, e oprimem inclusive a burguesia não-monopolista. O imperialismo, porém, limita o próprio desenvolvimento de grupos monopolistas brasileiros e possui conflitos também com interesses latifundiários. A batalha antiimperialista, por isto mesmo, está no centro da luta dos comunistas. O imperialismo responde, no Brasil como em todo o mundo, em primeiro lugar pela exploração econômica e pela opressão social e política. (Ibid., p. 156-6) 
Desse modo, de pouco adiantava a reiterada afirmação da centralidade da "luta pela conquista e ampliação contínua da democracia e as transformações econômico-sociais necessárias à sua conquista, consolidação e avanço, na medida em que o imperialismo e a reação interna, para garantirem sua dominação, concentram-se principalmente na supressão ou restrição da democracia" (Ibid., p. 158). Não adiantava também inverter a fórmula que traduzia o caráter da revolução brasileira - de "nacional e democrática” para "democrática e nacional". Na essência, a questão nacional mantinha sua primazia sobre a questão democrática. A centralidade pertencia à luta contra o imperialismo, o que favorecia um conteúdo nacionalista e permitia a aliança com setores burgueses (na prática uma reafirmação da velha fórmula da "burguesia nacional"). Por mais que se afirmasse também que a contradição entre burguesia e proletariado já havia assumido a centralidade no processo revolucionário brasileiro, na prática esse fator acabava secundarizado. O PCB permanecia com dificuldades de colocar o socialismo na ordem-do-dia.

A luta contra a ditadura avançava da forma que os pecebistas propunham. Eles não conseguiam, porém, traduzir aquele momento favorável à sua política em fortalecimento orgânico e influência social. Pelo contrário: perdiam progressivamente seu espaço entre os setores progressistas organizados da sociedade e no próprio campo das esquerdas. A esse respeito, é necessário comentar mais detidamente o surgimento no período de "setores modernos" do sindicalismo, responsáveis pela retomada do movimento sindical progressista nos últimos anos da década de 1970. Os atores dessas lutas eram trabalhadores organizados dos setores de ponta do capitalismo brasileiro, concentrados em grande parte na Região do ABC paulista.

Esses novos setores (que vieram a ser conhecidos como o "novo sindicalismo", ou "combativos") sustentaram a fundação de um partido dos trabalhadores (o PT), obtendo o apoio de setores da intelectualidade progressista, de setores progressistas da Igreja Católica (integrantes das comunidades eclesiais de base - CEB's), e da "esquerda revolucionária" (trotskistas, comunistas revolucionários e herdeiros da "esquerda armada" dos anos 1960), extremamente críticos ao PCB. O PT logo se definiu como uma alternativa "à esquerda" dos pecebistas, assumindo um papel oposicionista mais radical, avesso ao diálogo com o regime - criticando o "reformismo" da linha pecebista. 
No meio sindical, as diferenças se acentuaram. Desde as greves do final dos anos 1970, o PCB criticava o pretenso "radicalismo" e "voluntarismo" do "novo sindicalismo", enquanto este associava os pecebistas ao sindicalismo pré-1964, para eles "pelego" e "reformista". Tais posições acabaram levando os setores sindicais dos dois partidos a caminhos opostos, contribuindo para a formação de duas centrais sindicais: os petistas apoiaram decisivamente a fundação da Central Única dos Trabalhadores (CUT) em 1983, enquanto os pecebistas, por alegadas razões táticas, escolheram permanecer atrelados a setores conservadores do movimento sindical e participar da fundação da Central Geral dos Trabalhadores (CGT) em 1986. Aos pecebistas (que além de tudo fincavam raízes em setores mais "antigos" ou "tradicionais" da classe operária brasileira) pareceu mais seguro disputar espaço com os conservadores e fazer valer suas posições, buscando hegemonizar a CGT. A alternativa a isso seria conviver com os setores mais "combativos", que controlavam a CUT e possuíam, em relação ao $\mathrm{PCB}$, a vantagem de um discurso igualmente progressista, mas calcado numa inserção já consolidada nos setores sindicais sobre os quais a CUT tinha ascendência. De qualquer forma, a ilusão da possibilidade de hegemonia (ou mera sobrevivência) pecebista na CGT levou o partido a atuar por vários anos numa central sindical dividida e progressivamente enfraquecida, enquanto a CUT (hegemonizada pelo PT) atravessou a década de 1980 em constante crescimento.

Esses dois fenômenos - surgimento do "novo sindicalismo" e do PT - foram recebidos com extrema dificuldade pelos pecebistas. Especialmente o último se configurava como um fenômeno novo na política brasileira: um partido de massas com forte ascendência operária, grande inserção nos movimentos sociais e relacionado aos setores mais pujantes do movimento sindical. Ou seja, um partido com grande potencial para ocupar exatamente o espaço que o PCB buscava hegemonizar desde sua fundação. Sem dúvida, um adversário em potencial, que poderia tornarse um entrave ao projeto pecebista. Assim, os pecebistas nutriram um necessário respeito ao PT, ao mesmo tempo em que o acusaram de "sectarismo" ou "esquerdismo" em alguns momentos e de "socialdemocratismo" em outros. Os pecebistas iam reconhecendo aos poucos o crescimento e consolidação do PT (muitos a princípio apostavam em seu fracasso), ao mesmo tempo em que buscavam se diferenciar dele (declarando-se os verdadeiros representantes dos trabalhadores, por sua 
"experiência", "sensatez" política e a defesa aberta do socialismo). Tratava-se de uma maneira de manter a crença em dias melhores, que possivelmente viriam com a legalidade e a disputa em campo aberto. Quando isso ocorresse (acreditava-se), o PCB poderia recuperar seus dias de glória.

Não foi o que se viu. O PT ocuparia o papel de partido hegemônico nas esquerdas e no movimento sindical que outrora havia sido do PCB, tornando-se ainda uma real alternativa de poder (algo que o PCB, por contingências da política brasileira e de sua própria essência, nunca pôde ser). Assim, para muitos pecebistas ficou a percepção (correta, mas não exatamente pelos motivos apontados por eles) de que houve uma forte relação entre o surgimento do "novo sindicalismo" e do PT e o "ocaso" do PCB. É muito comum nos depoimentos colhidos a idéia de que houve um movimento consciente por parte do regime em retardar ao máximo a legalização do PCB, enquanto o PT, com a vantagem da legalidade, consolidava suas posições. Da mesma forma, o "novo sindicalismo" surgiria no espaço deixado pela repressão anterior ao sindicalismo e ao partido. Faz-se questão de desmistificar a "novidade" do "novo sindicalismo" e a representação dos trabalhadores reivindicada pelo PT:

Se pegar lá atrás no sindicalismo de São Paulo, o Lula entra no movimento sindical via intervenção do sindicato. Essa história do novo movimento sindical foi em função do esvaziamento, do espaço deixado em branco pelos comunistas e trabalhistas na época. [...] O PT não era partido operário, ninguém fala isso! Naquela hora o movimento operário era aquele ali. Mas se o PCB fosse legalizado naquela altura vinha com toda a tradição, com todos os companheiros vindos do exílio que estavam espalhados por aí, a intelectualidade que era do partido... Isso tudo foi absorvido pelo PT. O partido estava legal, a gente não era legal. Não tinha espaço na política (Gilvan Cavalcanti Melo).

A força contida em diversos depoimentos colhidos acerta do tema ao longo da pesquisa está na confirmação da importância atribuída à falta de representatividade dos pecebistas no renascente movimento sindical progressista e ao surgimento de um partido nos moldes do PT para o enfraquecimento do PCB. As explicações aventadas por esses atores nos dias de hoje podem não dar conta de tal fenômeno - ou pelo menos de 
seus principais fatores, já que algumas observações reproduzidas acima têm sua razão de ser pelo menos enquanto fatores secundários que aceleraram e consolidaram aquela tendência. Mas, de qualquer forma, a simples necessidade de formulação dessas explicações (temperadas com variadas doses de ressentimento) aponta o golpe que representou para os pecebistas a ascensão de um movimento de trabalhadores indiferentes ou francamente hostis ao PCB, e de um partido que se autoproclamava dos trabalhadores - igualmente indiferente ou mesmo hostil ao partido até então auto-referido como a vanguarda da classe operária. Agora, imensos setores do operariado rejeitavam aqueles que pretendiam representá-los. Certamente um duro golpe.

Por fim, vale destacar que naquele momento os países socialistas já davam sinais de desgaste na opinião pública mundial e claros sinais de dificuldades internas em diversos níveis (cf. Reis Filho, 1997). No entanto, o PCB continuava mantendo oficialmente sua imagem atrelada àquelas experiências: "A direção nossa, por uma série de razões (até pela luta com o Prestes) era uma direção afinada com a URSS (o Movimento Comunista Internacional era um elemento fundamental no jogo)" (Givaldo Siqueira. Depoimento cedido ao autor em 9 de setembro de 2003, no Rio de Janeiro-RJ). A direção pecebista em linhas gerais apoiava os regimes socialistas, mas progressivamente esse apoio vinha sendo marcado por certa dubiedade. Enquanto isso, um partido como o PT se posicionava criticamente em relação às experiências socialistas, evitando sua associação a "modelos" internacionais - como, de resto, a uma definição teórica mais clara. Considero que essa relação entre a crise do "socialismo real" e a crise pecebista existe - ainda que secundariamente, como "reforço" de outros fatores e, especialmente, de posterior fortalecimento das posições que defenderiam a liquidação da agremiação anos mais tarde.

\section{Entre a esperança e a decepção - o PCB na redemocratização (1984-1988)}

O PCB seguiu nos primeiros anos da década de $1980 \mathrm{em}$ seu "delicado equilîbrio" entre atuação institucional e luta de massas, entre o enfrentamento ao regime e o temor a um retrocesso na transição democrática. Tal linha de atuação ficou clara nos momentos centrais da redemocratização, entre 
1984 e 1985. Nos primeiros meses da campanha pelas Diretas Já para presidente (sustentada pela direção do PMDB, e imediatamente apoiada pelo PT), uma ausência sentida foi a do PCB. O partido sempre havia defendido coerentemente a proposta da Assembléia Constituinte - e mesmo após aderir à campanha, reafirmaria a centralidade da proposta de Assembléia Constituinte, à qual subordinava a luta por eleições diretas em todos os níveis. Além disso, é razoável supor que, naquele momento, lidando com suas lutas internas e retomando sua campanha pela legalidade, o partido estivesse num momento de certa paralisia decisória e excessivo temor em relação à possibilidade de um retrocesso na transição democrática, "motivado" pelas manifestações populares. Qualquer que tenha sido o motivo, o fato é que o PCB tardou a prestar apoio e a participar efetivamente do movimento, engajando-se nele apenas quando percebeu sua irreversibilidade.

Com a derrota no Congresso Nacional da Emenda Constitucional pelas eleições diretas em todos os níveis, o partido afirmou não ter preconceito em relação à negociação. Com o crescente deslocamento da "luta" para a "negociação", a opção mais viável passava a ser apoiar uma candidatura única de oposição no Colégio Eleitoral que se aproximava o que o PCB fez sem titubear, seguindo sua divisa de "lutar para negociar, negociar para mudar". Formada a "Aliança Democrática" (sustentada pelo PMDB e por dissidentes do regime reunidos na Frente Liberal), o PCB prestou apoio imediato à candidatura de Tancredo Neves e José Sarney, vitoriosa na votação indireta. Com o dramático adoecimento e falecimento de Tancredo, o partido seguiu apoiando o novo governo democrático (encabeçado por Sarney, que poucos meses antes era presidente do partido governista, o Partido Democrático Social - PDS) em seus primeiros anos, passando para a oposição apenas em 1988.

O PCB passou sem maiores dificuldades da defesa de diretas já para presidente ao apoio à candidatura indireta - a tal ponto que os dois momentos puderam ser lembrados a posteriori como um movimento contínuo:

Nós sempre participamos das eleições aí, levando em conta a perspectiva da vitória contra o regime ditatorial e aproveitando a brecha que eles davam para participar. Até que veio aquele grande movimento de Diretas Já, grandes comícios, grandes concentrações nas quais o partido estava inserido. Achei realmente correto. 
É bom assinalar que o PT era contra! [...] Era um período de transição para a democracia com voto direto, e eles não entenderam muito (ou não quiseram entender) na época. Às vezes é uma turma que eu fico olhando aí e dá a impressão de que eles é que realmente derrotaram a ditadura, e não foi bem assim... A história é outra. Um dia vai ser contada. (Geraldo Rodrigues dos Santos).

Um outro depoente relembraria aquele processo de forma mais detalhada. Com tudo o que pode ter de construção posterior, o trecho a seguir é bastante interessante, e permite compreender melhor a atuação do partido naquele período:

A gente trabalhou com várias alternativas. Uma delas, com um foco diferente, era a questão da luta pela eleição direta: forçar a ditadura a convocá-la. Ao mesmo tempo, a gente não tinha nenhuma ilusão de que ia haver essa convocação. Só com uma crise monumental, porque o projeto deles era fazer uma abertura "lenta e gradual". Então a gente trabalhava com essas duas visões. [...] O nosso objetivo qual era: era acabar com a ditadura, conquistar a democracia. Se isso fosse pela eleição direta... bom, muito bem, mas se fosse outra solução, dava no mesmo. Mas qual era a visão da esquerda? Era a idéia de confronto! Ou é eleição direta ou não é nada! Já a nossa política não. [...] O que interessava para nós? Era o fim da ditadura. E isso se deu pela via da negociação. Não havia ainda as condições para fazer o confronto. De outro lado a ditadura não ia fazer a abertura escancarada. Então tinha que fazer uma saída no sentido de romper com o bloco monolítico da ditadura. Toda a estratégia nossa era no sentido de romper esse bloco. Desse movimento se formou a Aliança Democrática [...] juntou o movimento de lutas, de massas, da sociedade organizada com a negociação, para fazer uma saída democrática que não fosse tão traumática nem para o regime militar nem que fosse o confronto final, a chegada da democracia que a gente desejava. [...] conseguimos o objetivo central nosso que era conquistar a democracia. (Gilvan Cavalcanti de Melo). 
Para uma melhor compreensão das razões da política pecebista naquele período, é importante lançar mão de seu programa recém-aprovado no VII Congresso. Nele, afirmava-se que o processo político brasileiro poderia seguir três direções:

A primeira é a da regressão política, pela via do golpismo, objetivando a manutenção dos traços centrais do regime. [...] A segunda perspectiva, passível de ser conjugada com a primeira, e na qual investem setores ponderáveis que sustentam o projeto de auto-reforma do regime, encontrando ressonância nos segmentos mais débeis da frente democrática, é a da "conciliação nacional" - um pacto de elites que, contemplando reivindicações de setores da oposição burguesa, conduza a um entendimento pelo alto, capaz de articular um novo respaldo político e uma base social mais larga para o regime reformado. A terceira perspectiva, que os comunistas avaliam como a mais favorável para a evolução do processo brasileiro, aponta na direção de uma solução política negociada para os impasses atuais. Trata-se de, à base da pressão organizada das massas, conquistar as condições sociais e políticas - no plano do movimento social e no plano institucional - para ultrapassar o regime e sua orientação econômico-financeira recessiva através de negociações que incluam setores do governo, do regime e do PDS. (Partido Comunista Brasileiro. 1983, p. 176.)

É razoável supor que, ao prestar apoio à Aliança Democrática, vários pecebistas entendessem que aquilo era a materialização desse terceiro caminho (o preferido pelo partido). No entanto, assim como na análise oficial do PCB a segunda alternativa era "passível de ser conjugada com a primeira”, parece ter escapado à compreensão pecebista naquele momento que a terceira opção também era passível de conjugação com a segunda - já que a realidade nunca é estanque a ponto de caber em esquematizações (por mais lúcidas que sejam). O processo brasileiro parece ter apresentado características dos dois últimos "tipos ideais" apresentados na análise pecebista: de fato ultrapassou o regime e em parte modificou sua política econômica, além de ter se dado de forma negociada e com a participação de setores do governo. Mas, ao mesmo tempo não deixou de 
ser majoritariamente um pacto de elites, assumindo caráter de "conciliação nacional” (expressão utilizada pelo próprio Tancredo Neves em sua campanha), em parte exatamente pela insuficiente participação das massas no processo - um fator importante para que o processo se desse da forma desejada pelo PCB (algo reconhecido pela própria análise do partido).

$\mathrm{O}$ que a maioria dos pecebistas não compreendeu em toda a sua extensão naquele momento foi a dimensão conservadora da transição brasileira. Pode-se recorrer aqui a Carlos Nelson Coutinho, que apontou a redemocratização brasileira como uma "transição fraca". Havia um "risco contido nessa forma de transição relativamente 'negociada'. Nela se verifica sempre [...] a combinação de processos 'pelo alto' e de processos provenientes 'de baixo'; e, decerto, é o predomínio de uns ou de outros o que determina o resultado final" (Coutinho, 1992, p. 52). Como naquela transição democrática predominaram as forças do "alto", ela terminaria por "reproduzir, ainda que 'atenuados' e 'modernizados', alguns dos traços mais característicos do tradicional modo 'prussiano' e 'passivo' de promover as transformações sociais no Brasil. Uma transição desse tipo - que poderíamos chamar de 'fraca' - implicava certamente uma ruptura com a ditadura implantada em 1964, mas não com os traços autoritários e excludentes que caracterizam aquele modo tradicional de se fazer política no Brasil" (Ibid., p. 53).

No entanto, malgrado o caráter conservador do novo regime, se completaria o longo processo de redemocratização, com o qual os pecebistas haviam contribuído com sua política de "frente democrática". Política que o partido, superado o regime ditatorial, manteve ao longo do que considerou um "período de transição", e que, assim como não vinha dando frutos mais práticos ao PCB nos últimos anos de autoritarismo, menos ainda os deu nos tempos da "Nova República". O autodenominado "artífice" da nova ordem (progressivamente desassociada de qualquer tipo de "transição forte") decaía, enquanto o (ao menos na aparência) partido anti-sistêmico consolidava-se. O PT - que havia se posicionado claramente contra a "transição pactuada", contra o Colégio Eleitoral e desde o primeiro dia contra o Governo Sarney - aparecia na nova fase democrática como o núcleo principal da oposição de esquerda, e o único em condições de apresentar uma alternativa progressista viável ao novo regime. O aumento de uma difusa percepção de que os sonhos democráticos acalentados por tanto tempo como a "cura" dos males nacionais 
não se realizariam na "Nova República" só iria consolidar a hegemonia petista entre a esquerda e os trabalhadores organizados. Por seu turno, a cada greve que ocorria (em geral liderada por sindicalistas ligados à CUT) o PCB fazia uma série de objeções, temendo que uma radicalização dos movimentos populares pudesse desestabilizar o novo regime. O PCB se declarava o "artífice" da nova ordem, por ter defendido a transição "negociada" desde seu início, mas se afastava cada vez mais das massas que julgava representar, enquanto "partido da classe operária".

O PCB acabou assumindo - mesmo que não fosse essa sua intenção - um papel de "contenção" no movimento sindical. Por outro lado, a década de 1980 representou de modo geral um período de ascenso (e radicalização) das lutas sindicais no país - o que se depreende do maior número de greves, aumento do número de sindicatos e sindicalizados, ascendência do movimento sobre a chamada "grande política", entre outros fatores (Cf. Santana, 2001 e 2003). Sem dúvida, a CUT e o PT eram não somente importantes para esse ascenso, como se valeram dele para a consolidação de suas posições. "Mesmo que relativizada, posteriormente, por esses dois agentes, a estratégia de enfrentamento dava frutos importantes nos setores organizados da sociedade" (Santana, 2001, p. 253). Com o tempo, os pecebistas reconheceram que a CGT era hegemonizada por setores conservadores, "pelegos" e "cupulistas", enquanto progressivamente se deu a aproximação entre as propostas sindicais cutistas e as defendidas pelo PCB. A central progressivamente abandonou a defesa da pluralidade sindical (execrada pelo PCB pelo seu potencial de pulverização e enfraquecimento do movimento), moderou sua defesa exacerbada da utilização da greve como instrumento de luta, substituindo progressivamente o perfil "combativo" pelo "propositivo".

Mais uma vez a política geral pecebista influiu fortemente em sua intervenção sindical. Novamente, porém, alguns sindicalistas do partido na prática encontraram outro caminho ao permanecerem ligados à CUT, exercendo assim certa autonomia e nunca deixando de reivindicar o apoio oficial do partido àquela central. No entanto, assim como a política geral dos dois partidos dificultava a aproximação entre suas bases sindicais, a proposta de filiação à CUT só ganharia força a partir do momento em que o PCB assumisse postura mais independente em relação ao governo da Nova República (1988). Mesmo assim, ainda seriam necessários cerca de dois anos para a vitória definitiva da proposta sindical mais progressista 
no seio do PCB. Enquanto isso, o partido seguiria amargando derrotas atrás de derrotas no movimento. Por um lado, perderia espaço para setores cutistas. Por outro, seu espaço no interior da CGT seria progressivamente dilapidado pelos conservadores, hegemonizados a partir de agora pelo "sindicalismo de resultados".

O PCB vinha de trinta e sete anos de ilegalidade. Nesse período, viveu situações diversas, que iam desde a "semilegalidade" até a mais violenta repressão (que quase extinguiu de fato o partido). Dificuldades que sem dúvida tiveram seu peso - ainda que secundário - no enfraquecimento do partido. Depois de intensa campanha e negociação pela sua legalização (iniciada em 1980, paralisada com a repressão policial ao VII Congresso no final de 1981 e retomada em 1983), finalmente chegava o tão aguardado momento da legalidade. O PCB finalmente podia mostrar sua face à sociedade, emergir depois de décadas de perseguições. Esse momento histórico trouxe novo ânimo à maioria dos pecebistas, e renovou as esperanças de uma retomada do poderio do velho partido. Porém, como temos visto até aqui, os tempos eram difíceis para o PCB. Os primeiros resultados eleitorais na legalidade foram muito aquém do esperado, o que começaria a minar a autoconfiança propagandeada pela direção pecebista. Como recorda um depoente,

Os resultados do PCB eram maiores, porque a gente colhia dentro do PMDB, então quando concorreu mesmo como PCB... A primeira eleição como PCB foi uma tragédia! No PMDB nós tínhamos oito deputados. Alguns nem aceitaram se filiar ao PCB. O Roberto [Freire] fez muita pressão, mas os únicos que aceitaram foram ele, Fernando Sant'ana e o [Alberto] Goldman (mesmo assim...). Mas o Tilden de Lima não aceitou, o Jackson Barreto... (Givaldo Siqueira)

O tom geral de otimismo e autopromoção da direção iria a partir dali iniciar uma lenta, mas constante inflexão. Em algum tempo, o PCB se assumiria como um partido em profunda crise, em busca de uma saída. Algo que militantes descontentes com os rumos da agremiação já haviam apontado anos antes a partir de óticas variadas, e que pecebistas não afinados com o discurso da direção continuavam a repercutir dia após dia. O resultado eleitoral era apenas mais um entre os aspectos mais visíveis 
de uma crise geral - ideológica, organizacional e de representação - que o partido vivia. Um período de tantas dificuldades e incertezas que é lembrado por ex-pecebistas de maneira radicalmente negativa: "A referência da esquerda era o PT, não éramos mais nós. Tanto que quando o PCB foi legalizado já estava praticamente morto, um partido que nasceu morto" (Gilvan Cavalcanti Melo)

Em 1987 foi realizado o VIII Congresso (Extraordinário) do PCB - envolto em certa emoção por ser o primeiro congresso legalizado em toda a trajetória do partido. As discussões públicas deflagradas pelo processo congressual, entretanto, demonstram que o partido permanecia dividido, e de maneira tão profunda que a situação tendia a se cristalizar, como frisa Zuleide Faria de Melo: "quando chegou o VIII Congresso a luta já estava bastante acirrada, aí já ficava claro que havia um divisor de águas realmente, o choque das idéias se refletia na realidade política, no movimento sindical, mostrava claramente que a rigor já haviam dois partidos". Givaldo Siqueira também aponta o VIII Congresso como um "divisor de águas": a partir dali começava a se definir com clareza um grupo contrário ao teor das transformações pelas quais o partido vinha passando, "um grupo de resistência, que antes não era transparente, não se assumia plenamente, vivia nas sombras, e que aí começa a se manifestar com muita clareza. Esse VIII Congresso foi uma demonstração disso. Os opositores chegaram ao final com vinte por cento dos votos, apoiados principalmente no município do Rio de Janeiro e com pequena representação em alguns outros estados". O recorrente dilema do PCB entre ser o partido da revolução ou das reformas, da classe operária ou do "povo brasileiro", se aprofundava ainda mais nesse momento.

No início de 1988, sua Executiva Nacional determinou que “o PCB assumirá uma firme postura de oposição à atual orientação do governo Sarney" (Givaldo Siqueira). Justificou-se tal posição com argumentos como a progressiva hegemonia dos setores conservadores no governo, e também com a proximidade do término da transição democrática. É necessário que se diga, porém, que tal posicionamento representou também um fortalecimento, no interior do partido, de setores mais à esquerda (além da crescente dificuldade em caracterizar o governo de transição como minimamente progressista), o que não significa que não houvesse mais setores favoráveis ao governo no interior da agremiação, ou que as profundas ligações de pecebistas com o PMDB não fossem se manter. 
Sintomaticamente, para as eleições presidenciais de 1989, alguns dirigentes do partido iriam defender o apoio a Ulisses Guimarães, o candidato do PMDB. Na concepção dos pecebistas, o período se encerraria com a promulgação da nova Carta, em 1988. Vale destacar que a defesa de uma Assembléia Constituinte havia sido uma proposta central na política "frentista" do PCB. Para a maioria dos pecebistas, a Constituinte (apesar de não ter assumido o formato de uma Assembléia Constituinte, mas de um Congresso Constituinte, limitado pelo fato dos seus membros participarem da legislação ordinária ao mesmo tempo, e de permanecerem como deputados após a promulgação da Carta) era carregada de simbolismo, e seu encerramento em 1988 marcou para o PCB o fim do processo de transição democrática.

O PCB teria extrema dificuldade em formular uma nova política, em meio a suas dilacerantes disputas internas. Num extremo, alguns setores do partido defenderiam o abandono do "frentismo" pecebista (que já havia se tornado um forte elemento de sua identidade), optando por uma aliança à esquerda, ao lado do PT. Em outro, seria defenderia uma "frente democrática", na prática uma manutenção da política antiditatorial em tempos democráticos (guindada finalmente a uma estratégia do partido). Determinando essa divisão, duas visões distintas: a primeira valorizando preferencialmente o conteúdo classista e revolucionário do partido e sua reinserção no movimento sindical progressista (elementos que vinham se perdendo); a segunda associando-se à idéia do PCB popular, democrático, reformador (componentes sempre presentes no partido, mas nunca com tanta força quanto agora). Não se encontraria uma síntese. Em breve, nem mesmo a preservação do partido seria possível - processo que em seus últimos momentos guardaria importantes relações com o desdobramento da crise nos países socialistas.

\section{Divisão da utopia - o destino do PCB em disputa (1989-1992)}

Nesse momento, o processo de definhamento do partido chegou ao ápice, concomitante ao colapso do "socialismo real". Constatada a gravidade da situação, foram levantadas numerosas possibilidades para a sua superação, e entre todas sairia "oficialmente" vitoriosa a da transformação do PCB em um novo partido, declarado "herdeiro" de parte de suas 
tradições. Tal processo levou ao que chamo de "diáspora pecebista": um grupo de militantes permaneceria organizado enquanto "PCB", buscando reproduzir (ou "resgatar") os aspectos mais "revolucionários" de sua identidade; outros seguiriam para o PT (consolidado naquele momento como o maior partido da esquerda brasileira); alguns buscariam o reencontro com a identidade comunista no Partido Comunista do Brasil (PC do B); e principalmente, muitos abandonariam definitivamente a militância partidária.

Nesse período, a relação de maior destaque se dá entre a derrocada do "socialismo real" no Leste Europeu e desintegração da URSS e as proposições pelo fim do PCB. Desde 1987, parte da direção pecebista conscientemente se aproveitou dos "novos ventos" internacionais para levar adiante transformações almejadas por certo setor do partido. Em primeiro lugar, aproveitando-se do "alargamento" da "camisa-de-força simbólica" internacional - fica cada vez mais evidente que, se não tinha seus rumos determinados pelas posições da URSS (tida tradicionalmente pelos pecebistas como "patria-mãe" do socialismo) e do Partido Comunista da União Soviética (PCUS, tido como seu "partido-guia"), o PCB tinha limitações de ordem simbólica dadas concretamente por sua filiação internacional. Em segundo lugar, brandindo as idéias simbolizadas pela perestroika na luta interna. Procurava associar-se o PCB à perestroika, que em seus primeiros anos vinha obtendo crescente aceitação entre os países capitalistas:

A influência [da perestroika] aqui no partido é evidente que se expressou porque a gente tinha a cultura de que tudo que partia da URSS era bom! Quando o Gorbachev assumiu nós também... A direção assumiu praticamente essa visão também. [A receptividade nas bases] foi problemática de um lado e do outro lado auspiciosa. O "oba-oba" era geral! Mudou mas não sabe por que mudou, não é? Do outro lado também os mais resistentes, os mais ortodoxos existiram. Dentro do mesmo grupo que aceitava a mudança porque não tinha outro jeito, porque vinha da URSS. Mesmo nesse grupo havia resistência (Gilvan Cavalcanti Melo).

Poderia se deduzir que a divisão que ia se delineando no partido se mantinha no que tange à aceitação ou não dos "ideais da perestroika". Por esse raciocínio, os que vinham aproximado o partido na prática de posições 
social-democratas teriam abraçado efusivamente a perestroika (buscando forças para uma suposta "perestroika no PCB", que o tornaria mais "aberto" e "plural"). Enquanto isso, os pecebistas contrários àquele projeto por qualquer motivo (associados nesse tipo de discurso inevitavelmente ao "conservadorismo", à "ortodoxia") teriam recebido os ideais da perestroika com variados graus de desconfiança. Tal discurso deve ser, no entanto, desmistificado pelo historiador, obrigado por dever de ofício a aproximarse o máximo possível da realidade que tenta compreender. E geralmente a realidade suplanta qualquer esquema "binário" de interpretação. É significativa neste sentido a declaração abaixo, proferida por uma das principais representantes do grupo que manteve o PCB, Zuleide Faria de Melo:

Eu acho que o Gorbachev realmente nos dois ou três primeiros anos de governo dele enganou direitinho a todos nós. [...] ele dizia uma coisa que parecia ser verdade: o lema era "mais democracia para mais socialismo". E a verdade não era essa: era menos democracia e menos socialismo. Só que ele conseguiu envolver isso aí num discurso tão bem elaborado - que ele é competente, disso aí não tenho dúvida nenhuma, é um salafrário, traidor, mas o discurso dele era muito atraente.

Portanto, a receptividade nas fileiras pecebistas à nova política soviética parece ter sido de fato bastante ampla a princípio. Descontado o sentimento de "russofilia", as diferentes correntes do partido conseguiam se identificar com um ideal caro à tradição socialista: "mais democracia para mais socialismo". Uma oposição mais aberta a tal programa só iria se delinear de fato quando dois fatores começassem a ficar claros aos atores envolvidos: em primeiro lugar, que as reformas implementadas na URSS com o objetivo declarado de recuperar e aprofundar o "socialismo real", ao invés de "curar o doente", estavam acelerando sua morte; em segundo lugar, que os ideais propagados pela perestroika vinham servindo de justificativa para transformações no PCB que poderiam, em última instância, levá-lo à extinção.

Nesse momento houve o interregno da campanha presidencial de Roberto Freire que, a princípio apenas uma tentativa de afirmação do partido no cenário da política brasileira (talvez apenas no cenário da 
esquerda) e uma tentativa de unificação de suas próprias fileiras, foi assumindo aos poucos uma aura de "novidade" para alguns setores da sociedade brasileira, em especial da intelectualidade. Teve sem dúvida uma força simbólica maior que o resultado final alcançado (o oitavo lugar geral, com cerca de $1 \%$ da votação total ou aproximadamente 769.000 votos). Expressões como "nova esquerda", "esquerda moderna" e "socialismo democrático" foram amplamente empregadas, sendo associadas a Freire e ao PCB. O candidato e seu vice (Sérgio Arouca) defenderam sistematicamente um "novo socialismo", democrático, defensor das liberdades, enquanto algumas críticas mais contundentes a países socialistas como Cuba e China foram proferidas. "Idéias-força" do "socialismo real", como a estatização, foram relativizadas. A crise do socialismo, que deu seus passos decisivos em plena campanha de Freire no Brasil, certamente serviu para reforçar e definir algumas das posições assumidas ao longo daquela campanha, que deflagrou o processo de transformação do PCB nos anos seguintes. Porém, tais posições refletiam em boa parte as mudanças pelas quais o partido vinha passando nos últimos anos, e representavam significativos setores pecebistas.

Nesse contexto a polêmica acerca da atuação sindical do PCB, que se arrastou por toda a década de 1980, sendo abafada em vários momentos, agora era retomada de forma irresistível. A realidade havia demonstrado o equívoco da atuação do partido junto aos setores mais conservadores do movimento sindical. A CGT (na qual os pecebistas buscavam levar adiante sua política de "unidade") serviu de "celeiro" a um "sindicalismo de resultados", em tudo diferente do que o partido defendia. A hegemonia da central, que os pecebistas esperavam conquistar derrotando os tradicionais, havia passado para as mãos de setores novos, forças conservadoras modernas, adaptadas à nova realidade do país. Estas afastaram da central tanto os tradicionais quanto os pecebistas (ironicamente companheiros dos "pelegos" também na derrota). Por seu turno, a atuação prática da CUT (naquele momento consolidada como central hegemônica, contrariando as previsões de muitos pecebistas de que ela não teria vida longa) já não diferia muito daquilo que o PCB defendia para o movimento sindical. Ao mesmo tempo, a central vinha perdendo em "combatividade". Sua atividade se moderava, lançando as bases para sua atuação defensiva nos anos 1990, focada na questão do emprego (cf. Santana, 2003). 
A história da atuação sindical pecebista naquela década é basicamente uma sucessão de derrotas: a perda de vários sindicatos (alguns tradicionalmente controlados por pecebistas) para setores cutistas que depois os filiavam à central, bem como a predileção dos novos sindicatos progressistas que surgiam pela filiação à CUT. Os espaços dos pecebistas se reduziam na CGT, mas principalmente fora dela. Em 1989, a direção sindical pecebista buscou ainda uma "solução intermediária": a atuação "eqüidistante" do partido, sem a opção definitiva por uma das centrais. Tal "solução" perdurou oficialmente até o ano seguinte, mas na prática os setores cutistas do PCB já eram amplamente majoritários, e a luta pela entrada na central acabou saindo vitoriosa do Encontro Nacional de Sindicalistas do PCB (Praia Grande, SP, 20 e 21 de outubro de 1990). Nele, finalmente optou-se pelo abandono da "política de eqüidistância" e pela atuação na CUT, decisão tomada por ampla maioria (apesar de alguns resistentes, argumentando que aquela reunião não tinha caráter deliberativo, tendo sido convocada apenas para discutir a crise vivida pelo partido e a eleição de sua direção sindical). De fato, os setores cutistas, cansados de indefinição e certos de sua maioria, impuseram a discussão e votação daquela proposta - numa espécie de "rebelião" das bases. Foi de fato uma vitória dos setores "à esquerda" do partido, mas na prática tal decisão não passava de "letra-morta". Apesar da atuação na CUT estar agora oficializada, o grau de dissensão no PCB era tal que alguns militantes permaneceram na CGT e muitos participaram das articulações para a fundação da Força Sindical (criada pelos “sindicalistas de resultados” em 1991). Àquela altu$\mathrm{ra}$, as divisões no partido se mantinham e se aprofundavam independentemente da posição oficial que fosse tomada.

Após as eleições presidenciais de 1989 (e especialmente após as eleições de 1990, na qual o PCB teve novamente resultados ínfimos), se deu um verdadeiro florescimento da diversidade nas fileiras pecebistas - talvez a maior em toda a trajetória do partido - na esteira da convocação do IX Congresso, realizado em 1991. Se configurou a princípio um amplo espectro de posições, que foi desde as abertamente social-democratas (como a do dirigente Jarbas de Holanda, que sairia do PCB no início de 1991 apontando o Partido da Social Democracia Brasileira (PSDB) como "alternativa de esquerda moderna" e a Força Sindical como "opção de sindicalismo plural") (cf. Holanda, 1991) num extremo, passando por propostas de fusão com o Partido Socialista Brasileiro (PSB), diluição no PT, 
extinção do partido, formação de uma nova agremiação, resgate do "revolucionarismo perdido" do PCB, até chegar ao outro extremo do espectro, habitado por militantes que não aceitavam maiores revisões da trajetória do partido e iriam se abrigar no PC do B (entre esses, os mais destacados eram os dirigentes Juliano Siqueira e Francisco Milani, que deixariam o partido logo após o IX Congresso).

Nesse meio-tempo, boa parte do núcleo dirigente assumiu abertamente a luta pela transformação completa do partido, baseada na crítica da experiência socialista, dos valores leninistas, do centralismo, da burocratização, do conceito de vanguarda, do partido único, da ditadura do proletariado. Transformação calcada no valor estratégico da democracia e na superação da dicotomia entre reforma e revolução. Grande parte dos militantes pecebistas não concordava com tais posições. A esses, indistintamente, os setores majoritários na direção rotularam de "conservadores". No entanto, deve-se frisar que

A crítica a essas teses nem sempre representou uma defesa irrestrita da ortodoxia. Será a maior ou menor ênfase na crítica à cultura e prática ortodoxa que determinará a heterogeneidade da oposição e os diferentes rumos que seus membros tomarão. Na dissidência havia o desejo de renovação - com caráter e conteúdo diferenciado da renovação modernizante da maioria capitaneada por Freire. Havia ainda elementos autocríticos em relação à práxis do partido nos últimos anos. Embora mantivessem conceitos e concepções ortodoxas, os dissidentes elaboraram uma reflexão crítica sobre o marxismo-leninismo e as experiências do socialismo real. (Silva, 1999)

Durante o processo congressual, a pluralidade de concepções do partido terminou por se agregar em três tendências. A maioria se agrupou em torno de Freire, Arouca e Salomão Malina, e se apresentou no congresso sob a alcunha de "Socialismo e democracia", defendendo "a renovação radical do partido. Isto significava abandonar a tradicional concepção de partido de quadros e da ditadura do proletariado e o desafio de construir uma nova teoria e organização partidárias. A maioria da DN [Direção Nacional] coloca em xeque a existência do PCB, seu nome, seus símbolos e a tradição histórica que estes encerram" (Ibid). A oposição 
tachada de "ortodoxa" se agrupou na tendência "Fomos, somos e seremos comunistas", capitaneada por Oscar Niemeyer, Francisco Milani, Horácio Macedo, entre outros. Defendia (ou buscava "resgatar") o caráter revolucionário do partido, sua estrutura leninista de organização e seus símbolos - muitos deles, porém, assumiam uma postura crítica em relação à experiência socialista e a alguns aspectos do marxismo-leninismo. Por fim, um outro grupo se configurou como uma "terceira via" entre o que classificava como "social-democracia" da primeira e "ortodoxia stalinista" da segunda. Era a "Política de esquerda pelo novo socialismo" (liderada por Domingos Tódero), que defendia a manutenção do nome e dos símbolos do partido, mas pugnava pela aprovação de boa parte das propostas transformadoras defendidas pela maioria - dando-lhes, no entanto, um caráter mais definidamente socialista.

O IX Congresso terminou com a esperada vitória do grupo de Freire (que foi eleito presidente do partido), porém por uma margem apertada: 53\%, contra 36\% da chapa "Fomos, somos e seremos comunistas" e 11\% da chapa "Política de esquerda pelo novo socialismo". As oposições somadas chegaram perto da maioria, inviabilizando momentaneamente o projeto de substituição imediata do PCB por um novo partido, com novo formato e sem um credo oficial marxista. As oposições obtiveram outra significativa concessão da maioria quanto à definição das forças políticas que poderiam integrar o "novo bloco político" proposto pela direção pecebista (como caminho para a construção de um novo pólo de poder contraposto à hegemonia conservadora vigente): "fizeram uma composição grande que a gente sabia que ia durar muito pouco tempo. $\mathrm{O}$ Roberto [Freire] na época fez uma 'concessãozinha' e botou 'frente democrática, progressista e de esquerda' [a princípio seria apenas democrática], e aí mudou tudo, não é? Servia para os dois lados. Um defendia a democracia e o outro defendia a frente de esquerda" (Gilvan Cavalcanti Melo).

Pouco depois, acontecimentos relacionados ao "socialismo real" (mais especificamente à URSS) seriam mais uma vez utilizados como pretextos para ações pecebistas, servindo então de "justificativa internacional" para a convocação do congresso (o X) destinado a encerrar a trajetória pecebista. O golpe de agosto de 1991 e os movimentos precipitados por ele - a perseguição aos comunistas soviéticos, o recrudescimento de sentimentos chauvinistas, a desintegração soviética - reforçaram as posições transformistas no interior do PCB (sendo utilizados nesse sentido pelos 
defensores dessas posições). Com essa justificativa - somada ao aprofundamento da crise brasileira ao longo daquele ano -, a maioria da direção pecebista decidiu acelerar o processo de mudanças, convocando " $\mathrm{O} X$ Congresso do PCB, em caráter extraordinário, a se realizar o mais breve possível, para discutir a constituição da nova formação política - o que inclui a nova forma-partido, seu nome e símbolo" (Diretório Nacional do PCB. "Resolução política do PCB (01/09/1991)". In: Partido Comunista Brasileiro, 1991, p. 81). A decisão pela convocação imediata de mais um congresso partidário parece ter sido tomada intempestivamente (talvez com a pressa necessária para se aproveitar um momento claramente favorável ao desejo de mudanças no partido), a se julgar pelo seguinte depoimento:

o congresso de mudança de nome foi uma coisa intempestiva. Saiu sem grande preparação. [...] o Roberto Freire convocou o congresso para mudar o nome do partido. Nós da executiva discutimos, concordamos inteiramente com o Roberto, então fomos para um congresso onde a questão era não as grandes transformações, ficou uma coisa retida, não houve uma grande acumulação nem dentro nem fora do partido (Givaldo Siqueira).

A oposição, dividida e sem poder contar com a estrutura e a preparação necessária (ao mesmo tempo em que setores dela aderiam ao PC do $\mathrm{B}$ e ao PT), lançou-se como pôde ao combate sem tréguas pela preservação do partido. $\mathrm{Na}$ seqüência da convocação do X Congresso, 29 membros da direção pecebista lançaram um comunicado, manifestando "seu mais veemente repúdio à postura liqüidacionista da maioria do Comitê Central, que convocou um Congresso Extraordinário, com a finalidade exclusiva de tentar extinguir o nosso partido, criando outro em seu lugar", denunciando "que essa convocação representa a capitulação ante a histeria anticomunista surgida após os acontecimentos da União Soviética e um golpe contra as deliberações do IX Congresso, recém realizado" (Partido Comunista Brasileiro, 1991, p. 83). A partir dali, não se mediriam palavras e ações, as partes em contenda perderiam definitivamente o sentimento de pertencimento à mesma organização:

definimos que [...] nós íamos começar a nos organizar, a briga ia ser agora pra valer e ia ser de forma clara, insofismável [...]. Desse 
período até o X Congresso foi (como a gente chama no interior) uma briga de foice no escuro. Você pode imaginar o que é uma briga de foice no escuro... [...] Aí era pra valer, era briga mesmo, sem princípio, sem nenhum compadrio [...] nós tínhamos delegados (e nisso a História ainda vai nos fazer justiça) que eram militantes do partido. Não era o caso do Roberto Freire (Zuleide Faria de Melo).

Essa é a mais comum contestação desse grupo em relação ao processo congressual. Deu-se aos não-filiados o direito de voto integral (quando este havia sido apenas parcial no congresso anterior), e os delegados ao congresso foram definidos nos chamados "fóruns socialistas", abertos à participação de todos os interessados. Sem dúvida, tal estratagema consolidou a vantagem dos setores majoritários - mas não se pode afirmar categoricamente que uma estruturação diferente do congresso pudesse modificar seus resultados, já que o momento era favorável aos que pretendiam abandonar os antigos paradigmas.

O processo congressual, sem maiores discussões senão acerca da mudança do partido, foi naturalmente polarizado entre apenas duas chapas: "Movimento socialismo e democracia", dos chamados "renovadores modernizantes"; e "Renovação revolucionária", dos que receberam a pecha de "ortodoxos". Vale notar, curiosamente, que ambos se definiram pela "renovação". O segundo grupo logo perceberia que sua luta seria inglória:

decidimos participar do congresso tentando fazer maioria. Logo vimos que isso seria impossível [...]. Aí, estabelecemos a tática de realizar um congresso paralelo também em São Paulo. Ao mesmo tempo, para não ficar um só dia sem registro, nós registramos, no Diário Oficial, o Partido Comunista - PC - como partido transitório [...] até a concretização da mudança de nome de PCB para PPS para que, então, pudéssemos requerer na justiça a sigla PCB e o nome Partido Comunista Brasileiro. (Ibid.)

Chegado o momento decisivo do X Congresso (sua fase final se realizou de 24 a 26 de janeiro de 1992), os "renovadores revolucionários" detinham cerca de um terço da representação. Dessa forma, não lhes restou 
alternativa - haja vista que não havia mais conciliação possível entre as duas concepções - a não ser abandonar o congresso, seguindo para seu "congresso paralelo" já previamente marcado de "reconstrução" do PCB. A maioria congressual, agora solitária, decidiria pela fundação do PPS. O "racha" estava caracterizado.

Para além do nascimento do PPS e de um PC (que lutaria nos anos seguintes, com sucesso, pela sua legalização enquanto "PCB”), é necessário registrar a verdadeira "diáspora" que se deu nesse momento - desde a preparação do IX Congresso até o encerramento do X. Um grande número de pecebistas decidiu seguir sua militância (ou reinventá-la) numa gama de outras organizações, mas fundamentalmente no PT e no PC do B. Além disso, deve-se lembrar do número incomensurável de pecebistas que abandonaram a atuação política, entre os quais muitos, desgostosos, perderam a referência de toda uma vida. Deu-se uma pulverização da militância pecebista (algo que de certa forma já vinha se dando, ainda que lentamente, durante todo o período analisado nestas páginas), de sua identidade, de sua memória. Caberia a partir de então a seus diversos "herdeiros” a reivindicação, manutenção, reprodução, renovação e manipulação de sua identidade, agora esfacelada.

\section{Conclusão}

Ao longo do período analisado aqui sucintamente o partido, como foi dito, foi perdendo progressivamente espaço nas esquerdas e nos movimentos sociais, enquanto o PT e a CUT ascendiam. Com a legalidade em 1985, os pecebistas foram obrigados a amargar ínfimos resultados eleitorais. Tiveram que conviver com crises internas que custaram esporádicas cisões e com a crise que acometia o "mundo socialista" e o pensamento marxista em geral. A derrocada do chamado "socialismo real" (19891991) seria o golpe final para o partido que, devido às experiências acumuladas nos anos anteriores, optou pela sua transformação em uma nova agremiação, o PPS - equilibrado entre referências a uma "nova esquerda" e a "herança" (selecionada) de um rico passado. Enquanto isso, um grande número de pecebistas decidiu seguir sua militância (ou reinventála) numa gama de outras organizações, enquanto alguns buscam "reconstruir o PCB". 
O PCB - dividido ao longo de sua trajetória entre a reforma e a revolução, entre ser representante do operariado ou do povo brasileiro, valorizar a democracia e o caminho pacífico ou a ditadura do proletariado e a insurreição (cf. Brandão, 1997) - não soube superar a "divisão de sua utopia" quando a nova configuração do país exigia uma opção mais clara pela "modernização" do partido. Assim, a persistência de concepções e práticas não adaptadas à nova realidade brasileira (não superadas graças à sua persistente dicotomia, que se manifestou com violência em seus últimos momentos) é a principal causa da crise final do partido.

$\mathrm{A}$ isso se juntaram as dificuldades pecebistas em lidar com a transição negociada (à qual terminou atrelado em posição subalterna), uma transição "fraca", com predominância dos interesses conservadores - o que não era, obviamente, a intenção do PCB. Com isso, o partido demorou muito a apoiar as Diretas Já (paralisado pelas suas disputas internas e defensor até o fim da proposta de Constituinte), apoiou corretamente a solução do Colégio Eleitoral e a Aliança Democrática, mas ficou subordinado àquele projeto sem maior independência, e depois disso também ao Governo Sarney. Já o PT e a CUT, assumindo posição radicalmente oposta à forma como se deu a transição e à "Nova República", se viabilizaram enquanto forças hegemônicas, respectivamente, nas esquerdas e no movimento sindical progressista. Por fim, outro fator importante (mas que teve seus momentos decisivos no período posterior ao analisado nesse trabalho) foi a crise e derrocada do mundo socialista, o que terminou por reforçar e legitimar tendências e posições já presentes no PCB, numa espécie de retirada da "camisa-de-força" internacional que o partido até então "simbolicamente" vestia.

\section{Referências bibliográficas}

BRANDÃO, Gildo Marçal. A esquerda positiva: as duas almas do Partido Comunista. São Paulo: Hucitec, 1997.

CARONE, Edgard. O PCB (v. 3 - 1964-1982). São Paulo: Difel, 1982.

COUTINHO, Carlos Nelson. Democracia e socialismo. São Paulo: Cortez, 1992.

Gramsci: um estudo sobre seu pensamento político. Rio de Janeiro: Civilização Brasileira, 1999. 
HOLANDA, Jarbas. Do PCB a uma esquerda moderna no Brasil. Novos Rumos, Brasília, Instituto Astrojildo Pereira, n. 20, 1991.

PANDOLFI, Dulce. Camaradas e companheiros: história e memória do PCB. Rio de Janeiro: Relume-Dumará, 1995.

PARTIDO COMUNISTA BRASILEIRO. Uma alternativa democrática para a crise brasileira (1983).

IX Congresso do Partido Comunista Brasileiro: caminhos e descaminhos. Florianópolis: 1991

POLLACK, Michael. Memória e identidade social. Estudos Históricos. Rio de Janeiro: v. 5, n. $10,1992$.

REIS FILHO, Daniel Aarão. Uma revolução perdida: a história do socialismo soviético. São Paulo: Fundação Perseu Abramo, 1997.

SANTANA, Marco Aurélio. Homens Partidos. São Paulo: Boitempo, Rio de Janeiro: Unirio, 2001.

. Trabalhadores em movimento: o sindicalismo brasileiro nos anos 1980-1990. In: FERREIRA, Jorge; DELGADO, Lucilia de Almeida Neves (Org.). O Brasil republicano. V. 4. Rio de Janeiro: Civilização Brasileira, 2003.

SILVA, Antônio Ozaí da. Os comunistas diante do muro: o marxismo-leninismo entre a negação e a afirmação da tradição stalinista. Diálogos. Maringá: Universidade Estadual de Maringá, v. 3, 1999.

Resumo: Esse artigo analisa a crise e divisão do Partido Comunista Brasileiro (PCB), processo que teve seus acontecimentos decisivos entre 1979 e 1992. Enquanto suas propostas para a redemocratização brasileira em boa parte foram vitoriosas (superação processual e pacífica da ditadura através da formação de uma ampla frente democrática intraclassista), o PCB encontrou sua maior crise.

Palavras-chave: Partido Comunista Brasileiro; socialismo; redemocratização brasileira.

Divided Utopy: the Brazilian Communist Party crisis (1979-1992)

Abstract: This article deals with the crisis of the- henceforth, PCB - a process which has its decisive moments between 1979 and 1992. Despite the fact that its proposals for the brazilian re-democratization were successful in a great deal (peaceful and processual overcoming of the dictatorship through the construction of a wide democratic intra-class coalition), the PCB met its greatest crisis.

Keywords: Brazilian Communist Party; socialism; brazilian re-democratization. 